\title{
Hemoglobin D to Total Hemoglobin Ratio Measurement
}

National Cancer Institute

\section{Source}

National Cancer Institute. Hemoglobin D to Total Hemoglobin Ratio Measurement. NCI Thesaurus. Code C147364.

The determination of the ratio of hemoglobin $\mathrm{D}$ compared to total hemoglobin present in a sample. The measurement may be expressed as a ratio or percentage. 